\title{
Space aliens and nonwords: Stimuli for investigating the learning of novel word-meaning pairs
}

\author{
PRAHLAD GUPTA, JOHN LIPINSKI, BRANDON ABBS, PO-HAN LIN, and EMRAH AKTUNC \\ University of Iowa, Iowa City, Iowa \\ DAVID LUDDEN \\ Lindsey Wilson College, Columbia, Kentucky \\ NADINE MARTIN \\ Temple University, Philadelphia, Pennsylvania \\ and \\ ROCHELLE NEWMAN \\ University of Maryland, College Park, Maryland
}

\begin{abstract}
We describe a set of pictorial and auditory stimuli that we have developed for use in word learning tasks in which the participant learns pairings of novel auditory sound patterns (names) with pictorial depictions of novel objects (referents). The pictorial referents are drawings of "space aliens," consisting of images that are variants of 144 different aliens. The auditory names are possible nonwords of English; the stimulus set consists of over 2,500 nonword stimuli recorded in a single voice, with controlled onsets, varying from one to seven syllables in length. The pictorial and nonword stimuli can also serve as independent stimulus sets for purposes other than word learning. The full set of these stimuli may be downloaded from www.psychonomic.org/archive/.
\end{abstract}

We have developed a simple theoretical framework for identifying and characterizing different aspects and elements of the learning of new words and a set of experimental tasks based on the framework, intended to apply to a variety of human subject populations. In these tasks, the participant is exposed to pairings of an auditorily presented novel sound pattern with the pictorial drawing of a novel object. The pictured objects we have devised are "aliens from other planets," drawn specifically to serve as interpretable but novel stimuli for which no previous names

This work was supported in part by a University of Iowa CIFRE grant to P.G.; by NIH Grant R01 DC01924 to N.M., P.G., and others; and by NIH Grant R01 DC006499 to P.G. The alien pictures were drawn by Chuck Dillon, and the nonword stimuli were recorded by Rebecca Reese. We thank Gary Dell, Eleanor Saffran, Myrna Schwartz, Larissa Samuelson, Jean Gordon, and Kirrie Ballard for helpful discussion. We also thank the people who participated in the digital processing of thousands of pictorial and auditory stimuli: Jill Arnold, Ryan Bankson, Scott Berman, Matt Brown, Tony Buhr, Sarah Eisenberg, Sara Even, Melissa Hodapp, Mark Hunter, Lindsay Jones, Naveen Khetarpal, Soo Kim, Dan Kresowik, Karen Langsam, Warren MacGregor, James Malicki, Kelly Matlock, Brooke McGinty, Nathan Miller, Jonathan Nauman, Sarah Oakley, Soumya Palreddy, Rebecca Reese, Milissa Reynolds, Laurel Sallade, Ellen Samuel, Kathleen Schnitker, Michal Schroeder, Sierra Spies, Emily Stiefel, David Stowe, Wendy Troob, Derek Van Horne, Alyssa Wiedenhoff, Linda Wood, and Jane Wu. Correspondence concerning this article should be addressed to P. Gupta, Department of Psychology, University of Iowa, Iowa City, IA 52242 (e-mail: prahladgupta@uiowa.edu). exist; there are 144 distinct aliens. The novel sound patterns are used as category names for the aliens and have been instantiated in the form of possible nonwords of English; we have created a database of auditory nonwords consisting of over 2,500 stimuli recorded in a single voice, with a controlled distribution of onsets, varying from one to seven syllables in length.

More detailed discussion of the theoretical framework and its rationale has been provided elsewhere, as have the results of our preliminary experiments employing the framework and the stimuli (Gupta, 2003; Gupta \& Lipinski, 2004; Gupta, Lipinski, Abbs, \& Lin, in press; Gupta, MacWhinney, Feldman, \& Sacco, 2003; Lipinski \& Gupta, 2003 , in press). The applicability of the paradigm to diverse populations has been established through its successful use with healthy college-age adults (Gupta, 2003; Gupta \& Lipinski, 2004); with 5- to 10-year-old children who had suffered perinatal brain lesions, as well as agematched healthy controls (Gupta et al., 2003); with older adults with acquired aphasia, as well as age-matched healthy controls (Martin, Gupta, Lipinski, Abbs, Schwartz, \& Dell, 2004); and with adolescents with specific language impairment (SLI), as well as age-matched healthy controls (Gupta, Tomblin, Abbs, \& Lipinski, 2004). The motivation for the present article is to describe and make available the stimuli themselves, in the hope that they may be useful to other researchers in investigation of word learning, and possibly also in other experimental contexts. 


\section{The Aliens}

We begin with a description of the stimuli that serve as referents. Our goal in creating referents for studying word learning was that they should belong to an inherently meaningful category, so there would be no difficulty in determining what kind of thing it was; however, there should be no preexisting name for the object. To this end, we created a set of drawings of "aliens from other planets," examples of which are shown in Figure 1. These stimuli can be presented simply as images of referents, as in Figures $1 \mathrm{a}$ and $1 \mathrm{~b}$, or with accompanying factual information; examples of one manner in which facts could be associated with the aliens are shown in Figures $1 \mathrm{c}$ and $1 \mathrm{~d}$.

One set of aliens has been designed to vary along three dimensions: head shape, number of arms, and type of nonhuman bodily appendage. Head shape can be humanlike, horizontally elongated, or vertically elongated; aliens can have either two or four arms; and nonhuman bodily appendages can be either a tail or a trunk-like appendage to the head. The crossing of these factors yields a total of 12

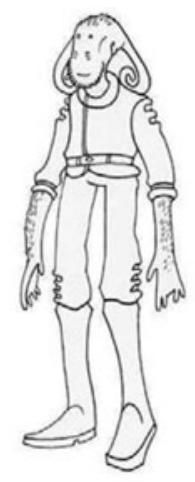

(a)

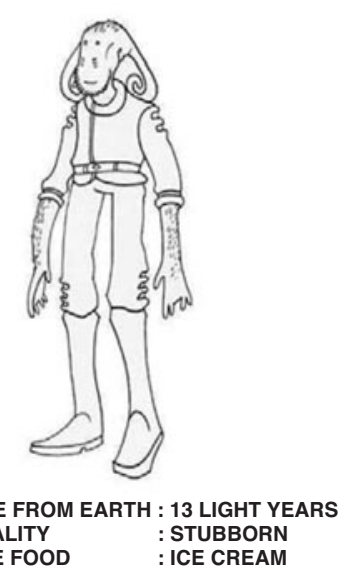

(c) combinations or cells in the design; Figure 2 provides an example of each of these cells. One set of 48 aliens consists of four aliens in each of these 12 cells (Set 1). A second set of 48 consists of aliens with two arms and no nonhuman appendages, who vary only in head shape (humanlike, vertically elongated, or horizontally elongated); there are 16 aliens with each of the three head shapes (Set 2).

A third set of 48 aliens (Set 3 ) varies along different dimensions: age, body shape, and head size. Age can be either adult or elderly; body shape can be either normal or rotund; head size can be either normal or oversize. The crossing of these factors yields a total of 12 cells. Four "families" of aliens have been created so that the members of one family appear similar to each other but occupy the 12 cells of this design; that is, the 12 aliens are variants of a prototype. The other three families consist of 12 variants of three different prototypes, for a total of 48 aliens in this third set, divided into four families.

Thus there are three sets of 48 aliens each, for a total of 144 distinct aliens. Each of these 144 aliens comes in three

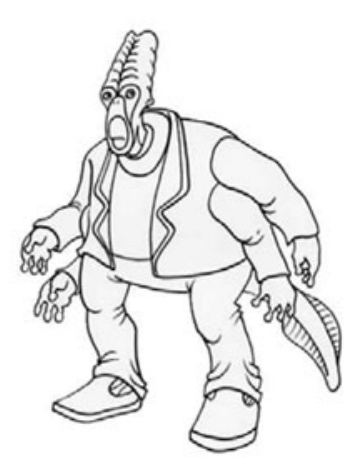

(b)

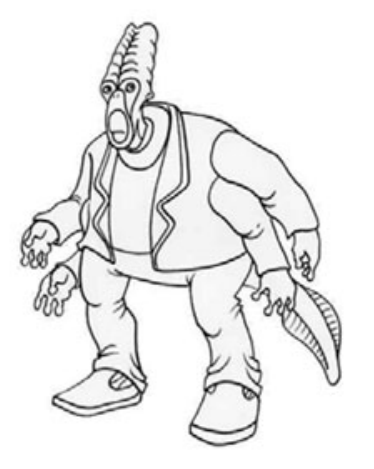

DISTANCE FROM EARTH : 51 LIGHT YEARS $\begin{array}{ll}\text { PERSONALITY } & \text { : WITTY } \\ \text { FAVORITE FOOD } & \text { : SPINACH }\end{array}$

(d)

Figure 1. Examples of "aliens" used as referents. (a) and (b) are visual images without any additional information. (c) and (d) are visual images of the same two aliens together with three "facts" presented in text form as part of the image. 

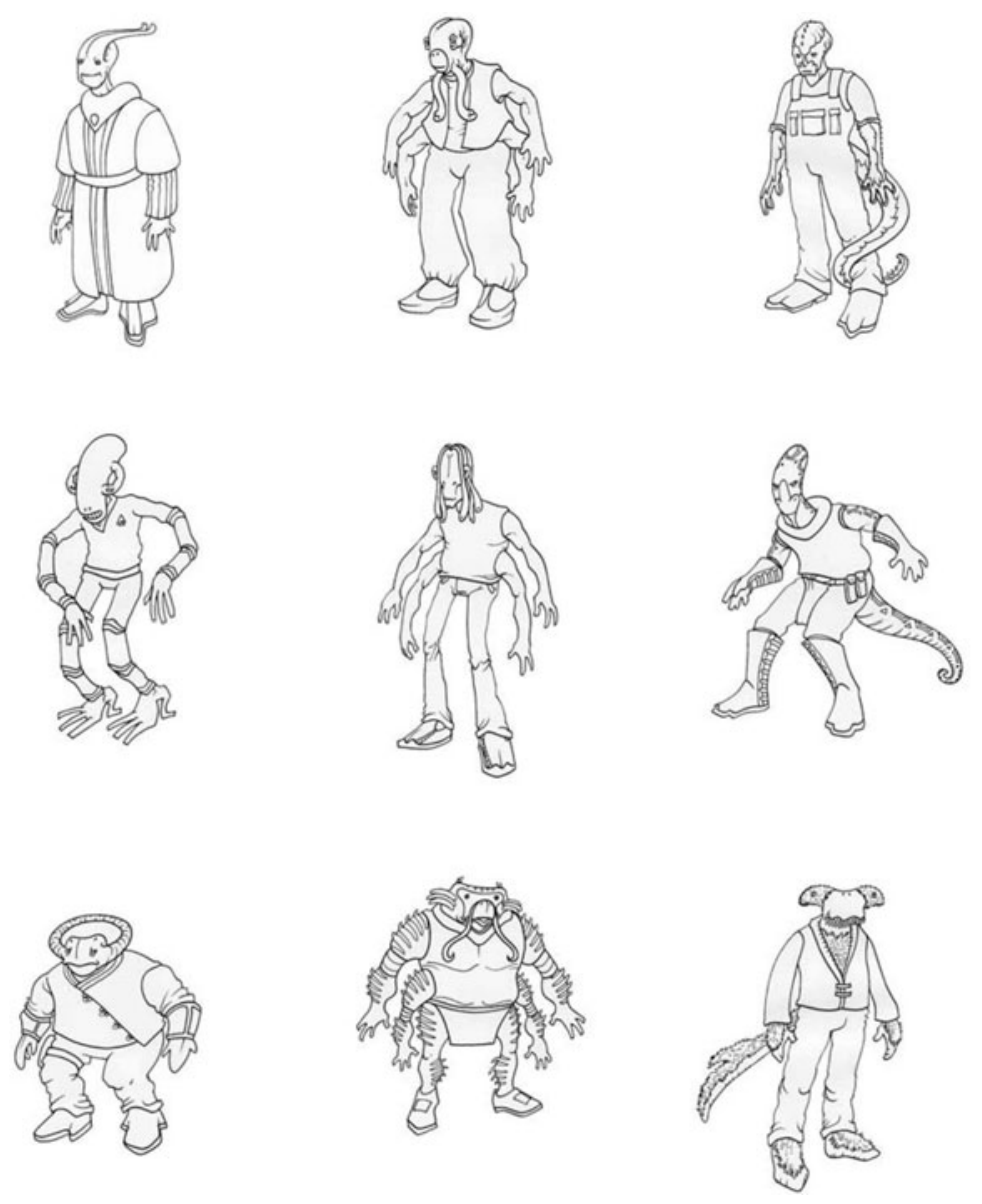
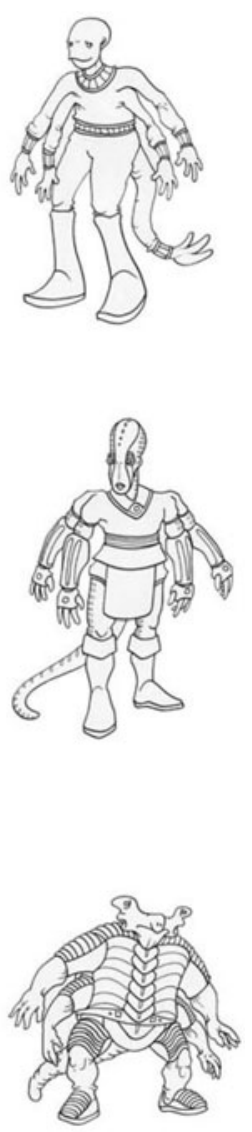

Figure 2. Examples of the 12 cells of the design for "Set 1 " aliens. Each row depicts a different head shape (top, humanlike; middle, vertically elongated; bottom, horizontally elongated). Within each row, the aliens depict, from left to right: head appendage and two arms; head appendage and four arms; tail appendage and two arms; tail appendage and four arms.

versions: one in full color, one in grayscale, and one in line drawing format, for a total of $3 \times 144=432$ images. The images in Figures 1 and 2 are in line drawing format.

All images are available as electronic files. We have used the Macintosh PICT graphical format, but the availability of graphical conversion software makes conversion to other formats relatively simple.

\section{The Nonwords}

In our word learning paradigm, participants are required to learn the pairings between visually presented images of aliens and auditorily presented category "names." The category names of the aliens consist of possible nonwords of English. We have created a database of nonwords varying from one to seven syllables in length. There are 420 nonwords each of two to four syllables in length, and 440 nonwords each of five to seven syllables in length. These polysyllabic nonwords all comprise CV nonfinal syllables and a CVC final syllable. The nonwords were generated orthographically in sets of 10 by a computer algorithm. In each set of 10 , onset consonants were drawn from the set $\{\mathrm{p}, \mathrm{t}, \mathrm{k}, \mathrm{b}, \mathrm{d}, \mathrm{g}\}$ with a specified probability distribution. All noninitial consonants (i.e., onsets of noninitial syllables, and codas of final syllables) were drawn from the set $\{b, k, d, f, g, l, m, n, p, r, s, t, v\}$ with a specified probability distribution. All vowels were drawn from the set $\{a, e, i, o, u\}$ with equal probability. Each orthographic string was then converted to a phonological encoding. For each nonword length, half the nonwords have primary stress on the penultimate syllable and half have primary stress on the antepenultimate syllable (except two-syllable nonwords, in which primary stress is placed on the first or last syllable in an equal number of stimuli). The total number of nonwords of two to seven syllables in length is $(3 \times 420)+(3 \times 440)=2,580$. Examples of these stimuli are given in the Appendix, which provides an IPA transcription as well as an English-like orthographic gloss for each nonword.

The one-syllable nonwords all have a CVC structure and are divided into sets of 20 . Each set of 20 contains two nonwords with each of the onsets $\left\{b, d, f, g, k, p, z, \int, t\right\}$, $\left.d_{3}\right\}$. Five of the sets of 20 consist of nonwords from high- 
density neighborhoods, and five consist of nonwords from low-density neighborhoods (Luce \& Pisoni, 1998), for a total of 100 low-density nonwords and 100 high-density nonwords and an overall total of 200 one-syllable nonwords. The mean frequency-weighted neighborhood densities (Luce \& Pisoni, 1998) are $37.01(S D=8.9)$ and $5.25(S D=3.05)$ for the high- and low-density stimuli, respectively. Examples of the one-syllable nonwords are, in IPA: /bis/, /k $\Lambda \mathrm{k} /$, / $æ \mathrm{n} /, / \mathrm{d} z \varepsilon \mathrm{k} /$, and /gut/.

Nonwords at each of the one- to seven-syllable lengths are thus divided into (and can therefore be selected in) sets that are equated for onsets, with the sets being of size 20 for one-syllable nonwords and of size 10 for the other lengths. Nonwords of two- to seven-syllable lengths additionally have other controlled phonotactic properties; the one-syllable nonwords additionally comprise two sets with different neighborhood densities. The database consists of $2,580+200=2,780$ nonwords in total, of one to seven syllables in length.

All of these nonwords have been recorded digitally at a sampling rate of $44.1 \mathrm{kHz}$. All stimuli were recorded in the same voice, by a female native speaker of American English. All stimuli are thus available in electronic format as digital sound files. We provide them in the WAVE audio format, although the availability of digital audio conversion software makes conversion to other formats relatively simple.

\section{Conclusions}

We have described two sets of stimuli that were designed to be used in, and have been used in, studies of word learning. Importantly, however, the stimulus sets could also be employed for other purposes. For instance, the third set of aliens described above (organized into four "families") could serve as stimuli in the study of categorization; they were designed partly with this in mind. The nonword stimuli could be used in studies of nonword processing more generally; in such studies, the elucidation of the relationship between known words and nonwords is of considerable importance to accounts of lexical processing. The one-syllable nonwords could be used in the investigation of neighborhood effects; we have used them for this purpose in other work (Lipinski \& Gupta, in press). More generally, the stimulus sets described here may be of use well beyond the context of the particular word learning studies that motivated them. We therefore hope that these stimuli may be of value to the research community; in word learning tasks, we have found them applicable for use with diverse human subject populations.

\section{REFERENCES}

Gupta, P. (2003). Examining the relationship between word learning, nonword repetition, and immediate serial recall in adults. Quarterly Journal of Experimental Psychology, 56A, 1213-1236.

GuPTA, P., \& LIPINSKI, J. (2004). Immediate serial recall and word learning: Is the relationship at phonology or semantics? Manuscript submitted for publication.

GuPTA, P., LiPINSKI, J., ABBs, B., \& Lin, P.-H. (in press). Serial position effects in nonword repetition. Journal of Memory \& Language.

Gupta, P., MacWhinney, B., Feldman, H., \& Sacco, K. (2003). Phonological memory and vocabulary learning in children with focal lesions. Brain \& Language, 87, 241-252.

Gupta, P., Tomblin, B., Abbs, B., \& Lipinski, J. (2004). Phonological priming and learning in SLI. Manuscript in preparation.

LIPINSKI, J., \& GUPTA, P. (2003). Separating the effects of duration and neighborhood density in nonword repetition latency. In R. Alterman $\&$ D. Kirsh (Eds.), Proceedings of the 25th Annual Conference of the Cognitive Science Society (p. 718). Mahwah, NJ: Erlbaum.

LIPINSKI, J., \& GUPTA, P. (in press). Does neighborhood density influence repetition latency for nonwords? Separating the effects of density and duration. Journal of Memory \& Language.

Luce, P. A., \& Pisoni, D. B. (1998). Recognizing spoken words: The neighborhood activation model. Ear \& Hearing, 19, 1-36.

Martin, N., Gupta, P., Lipinski, J., Abbs, B., Schwartz, M., \& Dell, G. (2004). Differentiating receptive and productive word learning in fluent aphasic patients. Manuscript in preparation.

\section{ARCHIVED MATERIALS}

The following materials associated with this article may be accessed through the Psychonomic Society's Norms, Stimuli, and Data archive, http://www.psychonomic.org/archive/.

To access these files or links, search the archive for this article using the journal (Behavior Research Methods, Instruments, \& Computers), the first author's name (Gupta) and the publication year (2004).

FILES: Gupta-BRMIC-2004-nw1.zip, Gupta-BRMIC-2004-nw2.zip, Gupta-BRMIC-2004-nw3.zip, Gupta-BRMIC-2004-nw4.zip, GuptaBRMIC-2004-nw5.zip, Gupta-BRMIC-2004-nw6.zip, Gupta-BRMIC2004-nw7.zip.

DESCRIPTION: The seven compressed archive files listed above each expand into a folder (i.e., directory). The seven folders together contain the 2,780 audio files constituting the various nonword stimuli described in this article, as well as lists of these stimuli and additional documentation. The audio files are in WAVE format and should be usable on both Macintosh and Windows computers.

FILE: Gupta-BRMIC-2004-a.zip.

DESCRIPTION: This compressed archive file expands into a folder containing the pictorial files constituting the various alien stimuli described in this article. These files are in Macintosh PICT format and should be usable on both Macintosh and Windows computers.

FILE: Gupta-BRMIC-2004.zip.

DESCRIPTION: This compressed archive file expands into a folder containing two README files. The file gupta2004nonwordsREADME.pdf describes the contents of the seven nonword stimulus archives. The file gupta2004aliensREADME.pdf contains a more detailed description of the alien stimuli described in this article, and the structure of the GuptaBRMIC-2004-a.zip archive. 
APPENDIX

Examples of Two- to Seven-Syllable Nonword Stimuli

\begin{tabular}{|c|c|c|c|}
\hline 2 syllables, stress 1 & & 5 syllables, stress 3 & \multirow{6}{*}{$\begin{array}{l}\text { /boøgi'neipitef/ } \\
\text { /disi'daneirab/ } \\
\text { /gusai'dæsokes/ } \\
\text { /komaI'soølimais/ } \\
\text { /tarku'seinoset/ }\end{array}$} \\
\hline BASSIM & /'bæsım/ & BOEGEENAYPEETEFF & \\
\hline DOCKOAN & /'dakoœn/ & DEECEEDONNAYROB & \\
\hline GILERE & /'gile../ & GOOSIGHDASSOKESS & \\
\hline KOOFOOP & /'kufup/ & KOMAYSOLEEMICE & \\
\hline PEGGUT & /'pegnt/ & TAIKUSANOSET & \\
\hline $\begin{array}{l}2 \text { syllables, stress } 2 \\
\text { BIPUP } \\
\text { DEEKEAD } \\
\text { GAYPOOM } \\
\text { KEEDOKE } \\
\text { TOEGUDD }\end{array}$ & $\begin{array}{l}\text { /bai'p } \Lambda \text { / } \\
\text { /di'ked/ } \\
\text { /gei'pum/ } \\
\text { /ki'doøk/ } \\
\text { /toø'g d/ }\end{array}$ & $\begin{array}{l}5 \text { syllables, stress4 } \\
\text { BIVONIENAILAIR } \\
\text { DAYMIKEYTECKEM } \\
\text { GOLOSOWSITTANE } \\
\text { KEENAYKOSIRRESS } \\
\text { PEATEETEEKAYSIN }\end{array}$ & $\begin{array}{l}\text { /baivo@nai'neiler/ } \\
\text { /deimaiki'tekem/ } \\
\text { /goloso'sitein/ } \\
\text { /kinerko'sires/ } \\
\text { /pititi'keIsin/ }\end{array}$ \\
\hline $\begin{array}{l}3 \text { syllables, stress } 1 \\
\text { BASSODOKE } \\
\text { DAYVAYTASS } \\
\text { GISSAYBIF } \\
\text { KOTIESOTE } \\
\text { TOVVIEDEEM }\end{array}$ & $\begin{array}{l}\text { /'bæsodoøk/ } \\
\text { /'deiveitæs/ } \\
\text { /'giseibif/ } \\
\text { /'kootaiso@t/ } \\
\text { /'tavaidim/ }\end{array}$ & $\begin{array}{l}6 \text { syllables, stress } 4 \\
\text { BIKIVISEENYBEEK } \\
\text { DEEDOOLYNELLOOMUG } \\
\text { GAIKAYKEEMECKOPEK } \\
\text { CAINOKEYGAYRAYSOLE } \\
\text { PEEKOOSAYDAVVOGICK }\end{array}$ & $\begin{array}{l}\text { /bi, kivi'sinibik/ } \\
\text { /di,duli'nclumıg/ } \\
\text { /ga, keıki'mekopek/ } \\
\text { /keI, nooki'geIreIsoøl/ } \\
\text { /pi,kuseı'dævogık/ }\end{array}$ \\
\hline $\begin{array}{l}3 \text { syllables, stress } 2 \\
\text { BISIRREL } \\
\text { DOOSENNANE } \\
\text { GEEFIRRASE } \\
\text { KEEGULOL } \\
\text { PYLESSIT }\end{array}$ & $\begin{array}{l}\text { /bai'sirel/ } \\
\text { /du'senein/ } \\
\text { /gi'fireis/ } \\
\text { /ki'gulal/ } \\
\text { /pai'lesit/ }\end{array}$ & $\begin{array}{l}\mathbf{6} \text { syllables, stress5 } \\
\text { BEEGAYDIGHTOSEMMADE } \\
\text { DUTIEFOTODOTOOT } \\
\text { GAYCITEENILAICERE } \\
\text { KEYBEETOOLYSISSATE } \\
\text { TONEEBOONAYNAMER }\end{array}$ & 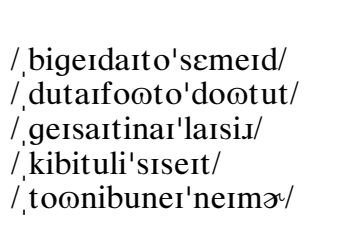 \\
\hline $\begin{array}{l}4 \text { syllables, stress } 2 \\
\text { BEENODOOFOP } \\
\text { DOEGEDIGHTEEL } \\
\text { GAINAYROKEVE } \\
\text { KOOSOSAYDEEG } \\
\text { PEANIRAINANE }\end{array}$ & $\begin{array}{l}\text { /bi'no@dufap/ } \\
\text { /doø'gedaitil/ } \\
\text { /gei'neIrokiv/ } \\
\text { /ku'so@seidig/ } \\
\text { /pi'ni.ıeınein/ }\end{array}$ & $\begin{array}{l}7 \text { syllables, stress5 } \\
\text { BEENEEFOTIESETOVODE } \\
\text { DOEMOOMEEMYTEEGEEPANE } \\
\text { GAIGAIKAYGAYKENNODOL } \\
\text { KAYTAYFIEKAYDIFFYSIDE } \\
\text { TOODYKITOTONNYTEM }\end{array}$ & 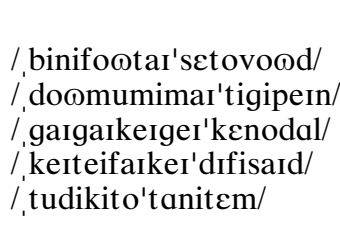 \\
\hline $\begin{array}{l}4 \text { syllables, stress3 } \\
\text { BIGHTIEVINNODE } \\
\text { DAYSOMAYSICE } \\
\text { GOROONEESORE } \\
\text { KYSORAYKOFE } \\
\text { TIETEENOOSOOSE } \\
\end{array}$ & $\begin{array}{l}\text { /baitai'vino@d/ } \\
\text { /deiso'meisais/ } \\
\text { /gooru'nisos/ } \\
\text { /kaiso'reiko@f/ } \\
\text { /taiti'nusus/ }\end{array}$ & $\begin{array}{l}7 \text { syllables, } \text { stress6 } 6 \\
\text { BAYDIETEEPEAFEESOOREET } \\
\text { DEESOOGEELIKEYFEETUKE } \\
\text { GUNUPEETEETAYREMMANE } \\
\text { KAIKOKAYGUIDEYTOSSET } \\
\text { PEAVAILEYEBUDUTONNUVE }\end{array}$ & $\begin{array}{l}\text { /bei, daItipifi'surit/ } \\
\text { /di, sugilarki'fituk/ } \\
\text { /guvnupititeI'remein/ } \\
\text { /kai, koøkeıgaIdi'taset/ } \\
\text { /pi,verlaIbudu'tanuv/ }\end{array}$ \\
\hline
\end{tabular}

(Manuscript received December 21, 2003; revision accepted for publication July 19, 2004.) 